\title{
PEMBUKTIAN TERBALIK KASUS TINDAK PIDANA KORUPSI DALAM PERSPEKTIF HAK ASASI MANUSIA
}

\author{
1Hasuri Hasuri, 2 Mia Mukaromah \\ 12Universitas Serang Raya \\ E-mail: majalah.assaadah@gmail.com, falsafamaitreya@gmail.com
}

\begin{abstract}
Corruption is considered a great crime and requires a planned response. The handling of the criminal act of corruption uses the reverse theory of proof or reversal of the burden of proof but in a balanced manner. The purpose of this study is to explain the reverse evidence of corruption from a human rights perspective. This research uses empirical normative legal research methods and literature study in collecting the necessary data. The study results state that the theory of reverse proof of corruption cases based on a human rights perspective does not violate the principles and respect for the rights of the defendants in the general principles of criminal law.
\end{abstract}

Keywords: Reverse Proof; Corruption; Human Rights

\begin{abstract}
Abstrak
Korupsi dianggap sebagai kejahatan yang luar biasa (extraordinary crime) dan memerlukan penanganan yang terencana. Penanganan tindak pidana korupsi menggunakan teori pembuktian terbalik atau pembalikan beban pembuktian namun secara berimbang. Tujuan penelitian ini untuk menjelaskan pembuktian terbalik kasus tindak pidana korupsi dalam perspektif Hak Asasi Manusia. Penelitian ini menggunakan metode penelitian hukum normatif empiris dan studi pustaka dalam mengumpulkan data-data yang diperlukan. Hasil penelitian menyatakan bahwa teori pembuktian terbalik kasus tindak pidana korupsi berdasarkan perspektif hak asasi manusia tidak melanggar prinsip dan penghargaan hak-hak terdakwa dalam asas umum hukum pidana.
\end{abstract}

Kata Kunci: Pembuktian Terbalik; Korupsi; Hak Asasi Manusia 


\section{Pendahuluan}

Pancasila dan UUD 1945 menjadi fundamental negara Indonesia dalam melakukan pembangunan nasional untuk mewujudkan masyarakat Indonesia yang adil, makmur, dan sejahtera. ${ }^{1}$ Usaha yang konsisten perlu terus ditingkatkan agar cita-cita bangsa dapat tercapai. Salah satunya adalah usaha pencegahan dan pemberantasan tindak pidana korupsi. Sekertaris jendral PBB Kofi Annan menyebutkan dalam kata pengantarnya pada Konvensi PBB mengenai Antikorupsi (United Nation Convention Against Corruption, 2003) bahwa korupsi menjadi wabah yang sangat berbahaya memiliki begitu banyak efek merusak terhadap masyarakat. Korupsi dapat melemahkan demokrasi dan supremasi hukum (the rule of law), menyebabkan terjadinya pelanggaran HAM, mengacaukan pasar, mengikis kualitas hidup dan membiarkan tumbuh subur kejahatan terorganisasi dan ancaman-ancaman lain terhadap keamanan umat manusia. Presiden Bank Dunia Jim Yong Kim menyatakan, korupsi merupakan permasalahan utama yang dihadapi negara-negara berkembang saat ini.

Indonesia salah satu negara berkembang mengalami kondisi yang cukup parah karena sebagian besar provinsi di Indonesia yang dipimpin kepala daerah tersangkut masalah hokum. ${ }^{2}$ Dari 32 gubernur, 17 diantaranya tersangkut perkara sehingga harus dinonaktifkan dari jabatan ${ }^{3}$. Berdasarkan data dari Kementrian Dalam Negeri sejak tahun 2004 hinggal Februari 2013, sedikitnya 291 kepala daerah baik tingkat provinsi maupun kabupaten/kota terlibat kasus korupsi. Jumlah tersebut terdiri dari gubernur sebanyak 21 orang, wakil gubernur 7 orang, bupati 156 orang, wakil bupati 46 orang, walikota 41 orang, dan wakil walikota 20 orang. Karena hal tersebut tidak mengherankan jika Survei Internasional yang diselenggarakan oleh badan Konsultasi Risiko Politik dan Ekonomi (PERC) Hong Kong pada 2004, telah menyebutkan Indonesia sebagai negara terkorup kedua di Asia setelah Vietnam. Bahkan pada tahun 2010 PERC menempatkan Indonesia pada posisi pertama sebagai negara terkorup dengan cetak skor 9,07 dari nilai 10 .

1 Fais Yonas Bo'a, "Pancasila Sebagai Sumber Hukum Dalam Sistem Hukum Nasional Pancasila as the Source of Law in the National Legal System," Jurnal Konstitusi 15, no. 1 (2018): 27-49.

2 Abdan Rahim, "Kepemimpinan Pendidikan Anti Korupsi Perspektif Pendidikan Islam," Al Falah 19, no. 1 (2019): 102-23.

3 Mansur Kartayasa, Korupsi Dan Pembuktian Terbalik Dari Perspektif Kebijakan Legislasi Dan Hak Asasi Manusia (Jakarta: Kencana, 2017). 
Dari paparan di atas dapat disimpulkan bahwa tindak pidana korupsi tidak mengalami penurunan bahkan cenderung meningkat, meskipun berbagai upaya telah dilakukan untuk mengatasinya. Berkaitan dengan hal tersebut pada rapat paripurna DPR RI mengenai Rancangan Undang-Undang RI perubahan atas Undang-Undang No. 31 Tahun 1999 Tentang Pemberantasan Tindak Pidana Korupsi menjadi Undang-Undang Nomor 20 Tahun 2001 pada tanggal 21 mei 2001 pemerintah menjelaskan pokok-pokok pikiran berkaitan dengan pemberantasan, diantaranya:

Pertama, diperlukan landasan hokum yang kuat dalam menegakkan hokum dan HAM yang berasaskan pada kebenaran, keadilan dan kepastian hokum. Upaya ini dilakukan untuk melaksanakan pemberantasan korupsi guna mengurangi kerugian Negara.

Kedua, kasus korupsi yang sistematik dan meluas, merupakan pelanggaran terhadap hak sosial dan ekonomi rakyat, tentunya juga merugikan keuangan Negara. Maka dari itu, korupsi harus di berantas dengan sistem yang terancana karena korupsi merupakan musuh bersama. Dengan demikian, pemberantasan tindak pidana korupsi harus dilakukan dengan cara yang khusus, antara lain dengan penerapan "sistem pembuktian terbalik" yakni pembuktian yang dibebankan terhadap terdakwa. Artinya, terdakwa sudah dianggap terbukti melakukan tindak pidana korupsi, seperti pegawai negeri yang menerima hadiah Rp. 10.000.000,- (sepuluh juta rupiah) atau lebih telah dianggap terbukti menerima suap, kecuali yang bersangkutan mampu membuktikan sebaliknya. Tetapi, penerima hadiah yang dibawah Rp. 10.000.000,(sepuluh juta rupiah), penyidikan dan penuntutannya berlaku sistem pembuktian biasa, yaitu jaksa yang harus membuktikan kesalahan terdakwa. Dengan kata lain jaksalah yang membuktikan dilakukan atau tidaknya suatu tindak pidana korupsi oleh seseorang.

Beberapa hasil penelitian terdahulu terkait pembuktian hokum lebih menfokuskan pda tahapan pembuktian peristiwa yang disengketakan. ${ }^{4}$ Penelitian lainnya tentang pembuktian hokum lebih menekankan kepada efektifitas pembuktian terbalik pada kasus kerugian keuangan

4 Elisabeth Nurhaini Butarbutar, "Arti Pentingnya Pembuktian Dalam Proses Penemuan Hukum Di Peradilan Perdata," Mimbar Hukum 22, no. 2 (2010): 347-59, https://doi.org/10.22146/jmh.16225. 
Negara. ${ }^{5}$ Disamping itu, Rozi (2018) yang mencoba menyajikan pembahasan mengenai Kitab Undang- Undang Hukum Acara Pidana (KUHAP) yang mengatur pembuktian dengan menggunakan alat -alat bukti yang legal. Akhirnya hasilnya penelitian Nurhayani lebih menekankan kepada pembuktian terbalik yang menganalisis penerapan pembuktian terbalik dalam kasus korupsi dan hambatannya. Berdasarkan beberapa hasil penelitian tersebut, maka penelitian ini terfokus kepada pembuktian terbalik tindak pidana korupsi dalam perspektif Hak Asasi Manusia.

Di sisi lain, metode pemberantasan tindak pidana korupsi dengan melakukan pembuktian terbalik yang menyebabkan beralihnya beban pembuktian dari tangan jaksa penuntut umum kepada tersangka atau terdakwa untuk membuktikan bahwa dirinya terbukti tidak bersalah. Apakah ketentuan tersebut bertentangan dengan kewajiban jaksa penuntut umum sebagai pihak yang mengajukan perkara untuk membuktikan perbuatan dan kesalahan yang dilakukan terdakwa, disamping itu hal tersebut tidak sesuai dengan asas praduga tak bersalah (presumption of innocent) dan asas tidak mempersalahkan diri sendiri (non self incrimination) yang merupakan perwujudan dari hak asasi manusia. Dari hal tersebut dapatlah ditentukan persoalan apakah pembuktian terbalik pada kasus tindak pidana korupsi melanggar Hak Asasi Manusia?

\section{Metodologi}

Penelitian ini menggunakan metode penelitian hukum normatif empiris. Metode ini menekankan pada penelitian yang melihat hokum dari segi kaidah/norma berupa peraturan perundang-undangan dalam menganalisis tindak pidana korupsi berdasarkan pembuktian terbalik. ${ }^{6}$ Untuk melengkapi data penelitian, studi pustaka sangat relevan dalam mengumpulkan informasi terkait tindak pidana korupsi.7 Penelitian ini menggunakan pendekatan analisis kualitatif yang bertujuan untuk menelaah seluruh data yang yang diperoleh peneliti dan selanjutnya ditafsirkan sesuai dengan tujuan penelitian.

5 Jawade Hafidz, "Efektifitas Pelaksanaan Sistem Pembuktian Terbalik Terhdap Perkara Korupsi Dalam Mewujudkan Negara Hukum Di Indonesia," Sultan Agung 14, no. 118 (2009): 39-64.

6 Depri Liber Sonata, "Metode Penelitian Hukum Normatif Dan Empiris: Karakteristik Khas Dari Metode Meniliti Hukum," Fiat Justisia Jurnal Ilmu Hukum 8, no. 1 (2014): 15-35.

${ }^{7}$ Nursapia Harahap, “Penelitian Kepustakaan,” Jurnal Iqra' 08, no. 01 (2015): 6873. 


\section{Pembuktian Terbalik Kasus Tindak Pidana Korupsi Perspektif Hak Asasi Manusia}

Andi Hamzah mengutip dari Fockema Andreae menjelaskan "korupsi" secara etimologis berasal dari bahasa latin corruption atau corruptus yang berasal dari kata corrumpere kemudian diadopsi oleh ke banyak bahasa seperti Inggris, corruption, corrupt, Perancis corruption. Belanda corruptie (korruptie) yang kemudian diadopsi dalam bahasa Indonesia menjadi korupsi. Dalam kamus umum bahasa InggrisIndonesia karangan S. WojoWasito, WJS. Poerwadarminta, SAM. Gaastra, JC. Tan (Mich) arti istilah corrupt ialah busuk atau buruk.

Di Indonesia, definisi korupsi adalah perbuatan yang buruk seperti penggelapan uang, penerimaan uang sogok dan sebagainya. Di Malaysia istilah korupsi dikenal dengan istilah resuah yang berasal dari bahasa Arab (riswah) yang merupakan perbuatan yang buruk. Perbuatan korupsi sebagai perbuatan pidana khusus yang dikategorikan sebagai kejahatan luar biasa (extraordinary crime) yang dalam penanganannya membutuhkan cara yang khusus.

Pengenalan terkait bentuk dan jenis korupsi dijelaskan dalam peraturan perundang-undangan. Diantaranya ketentuan lama peraturan Pemerintah Pengganti Undang-Undang (PERPU) No. 24 Tahun 1960 tentang Pengusutan, Penuntutan dan Pemeriksaan tindak pidana korupsi, mengenal tipologi tindak pidana korupsi sebagai berikut: Pertama, Tindakan seseorang yang dengan atau karena melakukan suatu kejahatan atau pelanggaran memperkaya diri sendiri atau orang lain atau suatu badan yang secara langsung atau tidak langsung merugikan keuangan atau perekonomian negara atau daerah atau merugikan keuangan suatu badan yang menerima bantuan dari keuangan negara atau daerah atau badan hukum lain yang menggunakan modal dan kelonggarankelonggaran dari negara atau masyarakat.

Kedua, Perbuatan seseorang yang dengan atau karena melakukan suatu kejahatan atau pelanggaran memperkaya diri sendiri atau orang lain atau badan dan yang dilakukan dengan menyalahgunakan jabatan atau kedudukan. Ketiga, Kejahatan-kejahatan yang tercantum dalam Pasal 17 sampai 21 peraturan ini dan dalam Pasal 209, 201, 415, 416, 417, 418, 419, 420, 423, 425 dan 435 Kitab Undang-Undang Hukum Pidana. 
Selain itu tipologi tindak pidana korupsi secara yuridis juga tercantum dalam Undang-Undang Nomor 3 Tahun 1971 (LN No. 17 TLN No. 2928) dan Undang-Undang Nomor 31 Tahun 1999 jo. UndangUndang Nomor 20 Tahun 2001 Tentang Pemberantasan Tindak Pidana Korupsi. Tindak pidana korupsi juga dapat dikatakan sebagai pelanggaran HAM karena tindakan tersebut telah merampas hak-hak masyarakat, baik sosial, ekonomi dan budaya.

\section{Instrumen HAM}

HAM secara universal melekat pada jati diri manusia dan bersifat mendasar ${ }^{8}$. HAM adalah hak yang dimiliki manusia sejak lahir. HAM pada dasarnya merupakan hak yang inherent dimiliki oleh setiap manusia sebagai makhluk Tuhan. ${ }^{9}$ Dalam terminologi hukum perdata, hak keperdataan seseorang itu telah diakui semenjak ia masih berada dalam kandungan. Pemikiran terkait HAM yang berhubungan dengan hak kodrati manusia yang melekat dan tidak bisa dipisahkan. Hak tersebut berupa hak perlindungan hidup, hak persamaan di mata hukum (equality before the law) dan hak untuk tidak diganggu atau disiksa.

Pasal 1 ayat (3) UUD 1945 telah menggariskan bahwa negara Indonesia adalah Negara hukum. Ini berarti Indonesia menghormati dan mengakui HAM sebagai hak semua rakyat Indonesia. Penjelasan terkait pasal tersebut bahwa, "Negara Indonesia berdasar atas hukum (rechstaat) tidak atas kekuasaan belaka (machtstaat)." Ketentuan tersebut, mengandung arti bahwa segala tindakan pemerintahan harus didasarkan atas hukum. Ruang lingkup HAM meliputi: a) Hak pribadi, hak-hak persamaan hidup, kebebasan, keamanan, dan lain-lain; b) Hak milik pribadi dan kelompok sosial tempat seseorang berada; c) Kebebasan sipil dan politik untuk dapat ikut serta dalam pemerintahan; serta, d) Hak-hak berkenaan dengan masalah ekonomi dan sosial.

Macam-Macam HAM: Pertama. Hak asasi pribadi/Personal Right: a. Hak kebebasan untuk bergerak, bepergian dan berpindah-pindah tempat, b. Hak kebebasan mengeluarkan atau menyatakan pendapat, c. Hak kebebasan memilih dan aktif di organisasi atau perkumpulan, d. Hak

8 Majda Muhtaj El, Hak Asasi Manusia Dalam Konstitusi Indonesia (Jakarta: Kencana, 2004).

9 Bambang Heri Supriyanto, "Penegakan Hukum Mengenai Hak Asasi Manusia (HAM) Menurut Hukum Positif Di Indonesia," Al-Azhar Indonesia Seri Pranata Sosial 2, no. 3 (2014): 151-68, https://jurnal.uai.ac.id/index.php/SPS/article/view/167/156. 
kebebasan untuk memilih, memeluk, dan menjalankan agama dan kepercayaan yang diyakini masing-masing. Kedua. Hak asasi politik/ Political Right: a. Hak untuk memilih dan dipilih dalam suatu pemilihan, b. hak ikut serta dalam kegiatan pemerintahan, c. Hak membuat dan mendirikan parpol/parta politik dan organisasi politik lainnya, d. Hak untuk membuat dan mengajukan suatu usulan petisi. Ketiga, Hak asasi hukum/Legal Equality Right: a. Hak mendapatkan perlakuan yang sama dalam hokum dan pemerintahan, b. Hak untuk menjadi Pegawai Negeri Sipil/PNS, c.Hak mendapat layanan dan perlindungan hukum. Keempat, Hak asasi Ekonomi/Property Rigths, d. Hak kebebasan melakukan kegiatan jual beli, e. Hak kebebasan mengadakan perjanjian kontrak, f. Hak kebebasan menyelenggarakan sewa-menyewa, hutang-piutang, dll, g. Hak kebebasan untuk memiliki sesuatu, h. Hak memiliki dan mendapatkan pekerjaan yang layak. Kelima, Hak Asasi Peradilan/Procedural Rights: a. Hak mendapat pembelaan hukum di pengadilan, b. Hak persamaan atas perlakuan penggeledahan, penangkapan, penahanan dan penyelidikan di mata hukum. Keenam, Hak asai sisosial budaya/Social Culture Right: a. Hak menentukan, memilih dan mendapatkan pendidikan, b. Hak mendapatkan pengajaran, dan c. Hak untuk mengembangkan budaya yang sesuai dengan bakat dan minat.

\section{Pembuktian dalam Sistem Peradilan Pidana}

Istilah pembuktian berasal dari kata "bukti" yang berarti suatu hal (persitiwa dan sebagainya) yang cukup untuk memperlihatkan kebenaran suatu hal (peristiwa tersebut). ${ }^{10}$ Pembuktian sebagai kegiatan membuktikan suatu peristiwa untuk menunjukkan benar atau tidaknya seorang terdakwa dalam persidangan. ${ }^{11}$ Dalam pengkajian secara yuridis, menurut M. Yahya Harahap, pembuktian merupakan ketentuan-ketentuan yang berisi penggarisan dan pedoman tentang cara-cara yang dibenarkan undang-undang membuktikan kesalahan yang didakwakan kepada terdakwa. Pembuktian sebagai salah satu cara untuk meyakinkan hakim agar ia dapat memutuskan suatu perkara yang menentukan terdawa itu

${ }^{10}$ Kartayasa, Korupsi Dan Pembuktian Terbalik Dari Perspektif Kebijakan Legislasi Dan Hak Asasi Manusia.

${ }^{11}$ Butarbutar, "Arti Pentingnya Pembuktian Dalam Proses Penemuan Hukum Di Peradilan Perdata.” 
bersalah atau tidak.12 Pembuktian pula mengatur alat-alat bukti yang dibenarkan undang-undang dan mengatur mengenai alat bukti yang boleh digunakan hakim guna membuktikan kesalahan terdakwa. Dalam pembuktian perkara pidana dikenal beberapa teori sistem pembuktian, yaitu:

Sistem pembuktian menurut undang-undang secara positif (posistief wettelijke bewijs theorie)

Teori ini menjelaskan bahwa alat-alat bukti merupakan dasar dalam sistem pembuktian positif sebagaimana disebut secara limitative dalam undang-undang. Undang-undang telah menentukan tentang alat bukti yang boleh dipakai oleh hakim, cara bagaimana alat bukti tersebut digunakan, kekuatan alat bukti tersebut dan bagaimana cara hakim harus memutus terbukti atau tidaknya perkara yang sedang diadili. Dalam hal ini berarti hakim terikat kepada undang-undang. Hakim harus menyatakan terdakwa bersalah jika alat-alat bukti yang digunakan membuktikan terdakwa bersalah walau hakim berkeyakinan bahwa sebenarnya terdakwa tidak bersalah. Begitupun sebaliknya, hakim harus rela menyatakan terdakwa tidak bersalah jika alat-alat bukti yang digunakan tidak membuktikan bersalah, walau hakim berkeyakinan bahwa terdakwa bersalah.

Sistem pembuktian menurut keyakinan hakim (conviction intime) conviction raisonee)

Teori ini menekankan kepada keyakinan hakim dalam membuat keputusan, hakim dapat menjatuhkan keputusannya berdasarkan keyakinannya dan tidak terikat oleh suatu peraturan. Pada sistem pembuktian ini keyakinan hakim memegang peranan penting untuk menentukan kesalahan terdakwa, namun keyakinan hakim tersebut harus dilakukan secara selektif dalam artian hakim dibatasi dengan harus didukung oleh alasan-alasan jelas dan rasional dalam mengambil keputusan, tidak semata mata atas dasar keyakinan yang tertutup tanpa uraian alasan yang masuk akal.

Sistem pembuktian menurut undang-undang secara negatif (negatif wettelijke bewijs theorie)

Teori ini memiliki prinsip bahwa sistem pembuktian menurut undang-undang secara negative menentukan bahwa hakim hanya boleh menjatuhkan pidana terhadap terdakwa apabila alat bukti tersebut secara

12 Fachrul Rozi, "Sistem Pembuktian Dalam Proses Persidangan Pada Perkara Tindak Pidana,” Jurnal Yuridis Unaja 1, no. 2 (2018): 19-33. 
limitatif ditentukan oleh undang-undang dan didukung oleh adanya keyakinan hakim terhadap eksistensinya alat-alat bukti tersebut. ${ }^{13}$ Dalam menentukan salah atau tidaknya seorang terdakwa menurut sistem pembuktian undang-undang secara negatif, terdapat du komponen: 1) Pembuktian harus dilakukan menurut cara dan dengan alat-alat bukti yang sah menurut undang-undang, dan 2) Dan keyakinan hakim yang juga harus didasarkan atas cara dengan alat-alat bukti yang sah menurut undang-undang

Dengan demikian, sistem ini memadukan unsur "objektif" dan "subjektif" dalam menentukan salah atau tidaknya terdakwa. Tidak ada yang dominan diantara unsur tersebut. Keduanya saling melengkapi dan mendukung dalam membuktikan kesalahan terdakwa. Jika salah satu unsur tidak terpenuhi maka terdakwa belum bisa dinyatakan bersalah.

Dalam pembuktian menurut hukum acara pidana Indonesia dalam membuktikan kesalahan terdakwa minimum terdapat dua alat bukti sebagaimana disebutkan dalam Pasal 183 KUHAP: "hakim tidak boleh menjatuhkan pidana kepada seseorang kecuali apabila dengan sekurangkurangnya dua alat bukti yang sah ia memperoleh keyakinan bahwa suatu tindak pidana benar-benar terjadi dan bahwa terdakwalah yang bersalah melakukannya." Secara limitatif bukti yang disebutkan dalam Pasal 183 KUHAP,yaitu: a. Keterangan saksi, b. Keterangan ahli, c. Surat, d. Petunjuk, e. Keterangan terdakwa. Bagi hakim, sekurang-kurangnya dua alat bukti sah yang telah ditetapkan oleh undang-undang dapat dijadikan sumber keyakinan hakim dalam menentukan kesalahan terdakwa.

Pembuktian Terbalik pada Kasus Tindak Pidana Korupsi dalam Perspektif Hak Asasi Manusia

Dalam ketentuan hukum acara pidana secara umum mengatur bahwa beban pembuktian dalam perkara tindak pidana umum diserahkan kepada jaksa penuntut, sedangkan tindakpidana korupsi sebagai tindak pidana khusus memiliki sifat pengecualian juga memiliki sifat khusus, baik yang berkaitan dengan hakim pidana materiil maupun formil. Hal itu didasarkan pada ketentuan Pasal 63 Ayat (2) KUHP : "apabila untuk suatu perbuatan yang telah diatur dalam suatu ketentuan pidana yang bersifat umum diatur pula oleh suatu ketentuan pidana yang

13 Yahya Harahap, Pembahasan Permasalahan Dan Penerapak KUHAP (Jakarta: Sinar Grafika, 2009). 
bersifat khusus, maka ketentuan pidana khusus inilah yang harus diberlakukan." Asasnya adalah lex specialis derogate legi generali.

Andi hamzah menganjurkan istilah yang digunakan adalah perundang-undangan pidana umum dan perundang-undangan pidana khusus. ${ }^{14}$ Yang dimaksud dengan perundang-undangan pidana umum adalah KUHP beserta semua perundang-undangan yang mengubah dan menambah KUHP. Adapun perundang-undangan pidana khusus ialah semua perundang-undangan di luar KUHP beserta perundang-undangan pelengkapnya, baik perundang-undangan pidana maupun yang bukan pidana tetapi bersanksi pidana. ${ }^{15}$

Undang-Undang Nomor 20 Tahun 2001 hasil pembaharuan dari Undang-Undang Nomor 31 Tahun 1999 Tentang Pemberantasan Tindak Pidana Korupsi merupakan jenis Tindak Pidana Khusus baik dilihat dari sudut pandang logis maupun sudut pandang yuridis atau sistematis. Tentang pembuktian penjelasan Undang-Undang Nomor 31 Tahun 1999 menyebutkan undang-undang ini menerapkan pembuktian terbalik yang bersifat terbatas atau berimbang. Yaitu terdakwa memiliki hak di dalam membuktikan bahwa terdakwa tidak melakukan korupsi dan wajib untuk dirinya memberikan penjelasan terkait harta benda setiap orang atau korporasi yang diduga mempunyai hubungan dengan perkara yang bersangkutan, dan penuntut umum tetap berkewajiban membuktikan dakwaannya.

Tentang pembalikan beban pembuktian, Undang-Undang Nomor 20 Tahun 2001 juga telah memperluas dalam penjelasan yang menyebutkan pembuktian terbalik ini diberlakukan juga pada tindak pidana baru tentang gratifikasi dan terhadap tuntutan perampasan harta benda terdakwa yang diduga dari salah satu tindak pidana. Ketentuan tersebut membuktikan bahwa Undang-Undang Tindak Pidana Korupsi merupakan hukum pidana yang bersifat khusus sehingga asas lex specialis derogate legi generali harus diberlakukan.

Pembuktian terbalik berhubungan dengan sistem dimana beban pembuktian berfokus pada terdakwa dan proses pembuktian ini hanya berlaku pada saat pemeriksaan di sidang pengadilan dengan dimungkinkannya dilakukan pemeriksaan tambahan atau khusus jika dalam

\footnotetext{
${ }^{14}$ Andi Hamzah, Asas-Asas Hukum Pidana ((Bandung: Rineka Cipta, 2008).

15 Kartayasa, Korupsi Dan Pembuktian Terbalik Dari Perspektif Kebijakan Legislasi Dan Hak Asasi Manusia.
} 
pemeriksaan persidangan diketemukan harta benda milik terdakwa yang diduga berasal dari tindak pidana korupsi namun hal tersebut belum didakwakan. ${ }^{16}$ Ketentuan tentang pembuktian terbalik atau pembalikan beban pembuktian tindak pidana korupsi dalam Undang-Undang Nomor 31 Tahun 1999 Tentang Pemberantasan Tindak Pidana Korupsi yang telah diperbaharui dengan Undang-Undang Nomor 20 Tahun 2001 Tentang Pemberantasan Tindak Pidana Korupsi maupun dalam UndangUndang Nomor 3 Tahun 1971 yang ditunjukan terhadap perbuatan kesalahan pelaku (Pasal 37) merupakan "pergeseran" (shifting) beban pembuktian atau "shifting of burden proof" bukan "reversal of burden proof" (pembalikan beban pembuktian) secara murni.

Hal tersebut dikarenakan terdakwa dapat membuktikan dirinya tidak bersalah atau tidak melakukan tindak pidana korupsi setelah diperkenankan oleh hakim. Selain itu, pembuktian bahwa terdakwa tidak melakukan tindak pidana korupsi tidak bersifat imperatif, karena merupakan hak terdakwa. Maksudnya, apabila terdakwa tidak menggunakan kesempatan ini maka hal tersebut justru akan merugikan dirinya sendiri dan dapat memperkuat dugaan penuntut umum bahwa terdawa memang benar telah melakukan tindak pidana korupsi. Sebaliknya, jika terdakwa dapat membuktikan bahwa ia tidak melakukan tindak pidana korupsi, maka hal tersebut akan menguntungkan bagi terdakwa. Dalam keadaan ini, jaksa penuntut umum tetap wajib membuktikan bahwa terdakwa bersalah melakukan tindak pidana korupsi, dengan demikian beban pembuktian diserahkan kepada keduanya, jaksa penuntut umum maupun terdakwa.

Jadi dalam teori pembuktian terbalik atau pembalikan beban pembuktian yang dianut oleh Indonesia bukan teori murni atau absolut melainkan hanya merupakan pergeseran beban pembuktian atau "shifting of burden proof". Hal ini disebabkan karena teori pembuktian terbalik secara murni atau absolut akan bersinggungan dengan Hak Asasi Manusia (HAM) khususnya implementasi terhadap ketentuan hukum acara pidana. Perlu ditegaskan bahwa dalam shifting of burden proof yang terjadi adalah "pergeseran" saja bukan "pembalikan" beban pembuktian, sehingga yang istilah populer pada Undang-Undang Nomor 31 Tahun 1999 tentang

${ }^{16}$ Hafidz, "Efektifitas Pelaksanaan Sistem Pembuktian Terbalik Terhdap Perkara Korupsi Dalam Mewujudkan Negara Hukum Di Indonesia.” 
Pemberantasan Tindak Pidana Korupsi dikenal dengan Sistem Pembalikan Beban Pembuktian Yang Terbatas atau berimbang.

Teori beban pembuktian berimbang dalam hukum positif Indonesia yang mengatur pemberantasan tindak pidana korupsi merupakan suatu conditio sine quanon, mengingat tindak pidana korupsi sudah menjadi tindak pidana yang bersifat luar biasa sehingga harus dihadapi secara luar biasa pula. Sistem pembuktian dalam proses perkara tindak pidana korupsi yang dianut suatu negara pula akan berpengaruh terhadap keberhasilan pemberantasan korupsi di negara bersangkutan. ${ }^{17}$ Apabila sistem yang dianut masih menggunakan sistem pembuktian dengan beban pembuktian berada dipihak penuntut umum sepenuhnya yang didasarkan pada presumption of innocence secara mutlak, upaya pemberantasan tindak pidana korupsi yang dilakukan tidak akan mencapai hasil yang maksimal.

\section{Penutup}

Pembuktian sebagai salah satu cara untuk meyakinkan hakim agar ia dapat memutuskan suatu perkara yang menentukan terdawa itu bersalah atau tidak. Pembuktian merupakan hal yang sangat penting dalam proses persidangan. Hal yang pokok dalam pembuktian adalah alat-alat bukti. Dalam menentukan suatu perkara sedikitnya harus ada dua alat bukti yang sah yang telah ditetapkan oleh undang-undang. Teori pembuktian terbalik atau pembalikan beban pembuktian pada kasus tindak pidana korupsi di Indonesia tidak menganut secara mutlak melainkan hanya sebagai "pergeseran" yang dikenal dengan istilah teori pembuktian berimbang. Dengan teori pembuktian berimbang maka pembuktian bukan saja dibebankan pada terdakwa melainkan pada jaksa penuntut umum pun harus dapat membuktikan bahwa terdakwa bersalah. Dengan itu, ketentuan teori pembuktian berimbang tidak melanggar prinsip Hak Asasi Manusia dan penghargaan hak-hak terdakwa dalam asas umum hukum pidana yang menyatakan siapa yang menuntut, dialah yang harus membuktikan kebenaran tuntutannya.

17 Wahyu Wiriadinata, “Korupsi Dan Pembalikan Beban Pembuktian," Jurnal $\begin{array}{llllll}\text { Hukum \& Pembangunan 43, no. } 1 & \text { (2017): }\end{array}$ https://doi.org/10.21143/jhp.vol43.no1.1508. 


\section{Daftar Pustaka}

Bo'a, Fais Yonas. "Pancasila Sebagai Sumber Hukum Dalam Sistem Hukum Nasional Pancasila as the Source of Law in the National Legal System." Jurnal Konstitusi 15, no. 1 (2018): 27-49.

Butarbutar, Elisabeth Nurhaini. "Arti Pentingnya Pembuktian Dalam Proses Penemuan Hukum Di Peradilan Perdata." Mimbar Hukum 22, no. 2 (2010): 347-59. https://doi.org/10.22146/jmh.16225.

El, Majda Muhtaj. Hak Asasi Manusia Dalam Konstitusi Indonesia. Jakarta: Kencana, 2004.

Hafidz, Jawade. "Efektifitas Pelaksanaan Sistem Pembuktian Terbalik Terhdap Perkara Korupsi Dalam Mewujudkan Negara Hukum Di Indonesia." Sultan Agung 14, no. 118 (2009): 39-64.

Hamzah, Andi. Asas-Asas Hukum Pidana. (Bandung: Rineka Cipta, 2008.

Harahap, Nursapia. "Penelitian Kepustakaan." Jurnal Iqra' 08, no. 01 (2015): 68-73.

Harahap, Yahya. Pembahasan Permasalahan Dan Penerapak KUHAP. Jakarta: Sinar Grafika, 2009.

Kartayasa, Mansur. Korupsi Dan Pembuktian Terbalik Dari Perspektif Kebijakan Legislasi Dan Hak Asasi Manusia. Jakarta: Kencana, 2017.

Rahim, Abdan. "Kepemimpinan Pendidikan Anti Korupsi Perspektif Pendidikan Islam." Al Falah 19, no. 1 (2019): 102-23.

Rozi, Fachrul. "Sistem Pembuktian Dalam Proses Persidangan Pada Perkara Tindak Pidana." Jurnal Yuridis Unaja 1, no. 2 (2018): 1933.

Sonata, Depri Liber. "Metode Penelitian Hukum Normatif Dan Empiris: Karakteristik Khas Dari Metode Meniliti Hukum." Fiat Justisia Jurnal Ilmu Hukum 8, no. 1 (2014): 15-35.

Supriyanto, Bambang Heri. "Penegakan Hukum Mengenai Hak Asasi Manusia (HAM) Menurut Hukum Positif Di Indonesia." Al-Azhar Indonesia Seri Pranata Sosial 2, no. 3 (2014): 151-68. https://jurnal.uai.ac.id/index.php/SPS/article/view/167/156.

Wiriadinata, Wahyu. "Korupsi Dan Pembalikan Beban Pembuktian." Jurnal Hukum \& Pembangunan 43, no. 1 (2017): 117. 
170 | Adliya: Jurnal Hukum dan Kemanusiaan, Vol. 14, No. 2, Desember 2020 https://doi.org/10.21143/jhp.vol43.no1.1508. 